\title{
KINERJA TUTOR DALAM PROSES PEMBELAJARAN PAKET C
}

\author{
Lambok Amran Adrianto*
}

\begin{abstract}
The purpose of this research is to obtain empirical data on tutor's performance in managing instructional activities of Package C Program at Community Learning Activities Center (CLAC). The research was conducted at a CLAC in North Jakarta. The method employed was descriptive method with qualitative approach. The researcher made direct observation to the CLAC where Package C program was being implemented. To obtain valid and reliable data and information, the researcher also conducted in-depth interview. Based on the available data and information, the research concluded that according to the respondents' opinion all tutors have conducted instructional process in the line with the existing standard procedures. The tutors make a good preparation before instructional process and they are capable enough to perform their tasks professionally. They have a good mastery of the instructional materials and sound ability to use appropriate instructional media to improve participants' learning achievement. For a better result in the future, the tutors are suggested to be more proactive to develop their knowledge and skills related to their job.
\end{abstract}

Keywords: tutor, community learning activities center, package c, performance

\begin{abstract}
Abstrak
Penelitian ini bertujuan untuk memperoleh data empiris tentang kinerja tutor dalam mengelola kegiatan pembelajaran pada Program Paket C di PKBM Mekar Tanjung. Penelitian ini dilaksanakan di PKBM Mekar Tanjung yang bertempat di Jakarta Utara. Metode penelitian yang digunakan dalam penelitian ini adalah metode deskriptif dengan pendekatan kualitatif. Peneliti mengadakan observasi langsung ke lokasi penyelenggaraan Kejar Paket $C$ dan data dikumpulkan melalui pengamatan dan wawancara mendalam. Kesimpulan penelitian ini adalah responden menyatakan seluruh tutor telah melakukan proses pembelajaran sesuai dengan ketentuan yang dijadikan tolok ukur kinerja tutor. Tutor melakukan persiapan sebelum proses pembelajaran dan tutor dianggap sudah kompeten dalam pemberian materi maupun menggunakan media pembelajaran sehingga dapat dikatakan tutor telah mampu mengelola kegiatan pembelajaran pada program paket C di PKBM Mekar Tanjung Jakarta Utara. Peneliti menyarankan agar perlu diperhatikan oleh pihak penyelenggara adalah peningkatan media pembelajaran untuk meningkatkan hasil pembelajaran dan tutor hendaknya lebih membuka diri untuk berusaha meningkatkan wawasan, pengetahuan dan pemahaman materi untuk meningkatkan kinerjanya.
\end{abstract}

Kata-kata kunci: tutor, pusat kegiatan belajar masyarakat, paket c, kinerja.

\section{PENDAHULUAN}

\section{Latar Belakang Masalah}

Pendidikan merupakan hal penting bagi kehidupan umat manusia. Pendidikan dapat dikatakan sebagai salah satu kebutuhan yang paling mendasar bagi setiap orang, dengan pendidikan setiap orang dapat menjadi manusia-manusia berkualitas yang akan mampu menghadapi tantangan kehidupan yang dari waktu ke waktu semakin kompleks. Perkembangan

* Alumni Jurusan PLS FIP UNJ zaman, belakangan ini sudah sangat maju, tetapi kurang diikuti dengan perkembangan sumber daya manusianya sebagai penggerak atau motor, di lain pihak masih banyak warga masyarakat yang tidak bisa membaca, jangankan untuk sampai ke jenjang pendidikan yang setara dengan perguruan tinggi, untuk sampai ke jenjang pendidikan setara sekolah menengah saja masih banyak masyarakat yang tidak dapat mengikutinya, ini dipicu karena mahalnya biaya 
pendidikan di Indonesia pada umumnya dan di kota besar seperti Jakarta pada khususnya sehingga hal inilah yang memacu pemerataan pendidikan di Jakarta belum sepenuhnya dapat dirasakan oleh masyarakat.

Kesempatan mendapat pendidikan dapat dikatakan sebagai hak asasi yang dimiliki setiap anak Indonesia yang dibawanya sejak dilahirkan. Ironisnya, tidak semua anak usia sekolah dapat menyelesaikan pendidikannya hingga tamat, hal ini dikarenakan ketidakmampuan orang tua, sehingga mengakibatkan bertambahnya jumlah angka anak putus sekolah. Kenyataan banyaknya angka anak yang putus sekolah merupakan hal yang sangat memprihatinkan. Anak usia sekolah yang tidak dapat melanjutkan sekolah dikarenakan terbatasnya kemampuan finansial dapat melanjutkan kembali sesuai dengan jenjang pendidikan terakhirnya, hal ini sesuai dengan Undang-undang Nomor 20 Tahun 2003 tentang Sistem Pendidikan Nasional yang menyatakan "Pendidikan dapat dilaksanakan melalui tiga jalur yaitu jalur pendidikan formal, nonformal, dan informal."

Pendidikan nonformal merupakan jalur pendidikan yang menyesuaikan kurikulum dengan kebutuhan warga belajarnya, dan juga menyesuaikan antara waktu belajar dengan aktivitas dari warga belajarnya itu sendiri, karena peserta belajarnya terdiri dari orang-orang yang telah bekerja dan harus disesuaikan dengan kondisi yang ada. Memang pendidikan nonformal atau biasa dikenal dengan sebutan pendidikan luar sekolah memiliki tujuan yang sama dengan tujuan pendidikan nasional juga, di mana Pendidikan Luar Sekolah (PLS) ingin menciptakan manusia yang diharapkan nantinya dapat berdaya guna, dengan cara memberikan life skill (keterampilan hidup) yang nantinya setelah memiliki keterampilan diharapkan dapat memenuhi kebutuhan hidupnya sehari-hari.

Salah satu lembaga, organisasi, atau komunitas belajar yang menyelenggarakan pendidikan nonformal adalah Pusat Kegiatan Belajar Masyarakat (PKBM). PKBM adalah salah satu lembaga Pendidikan Luar Sekolah (PLS), yang tujuan dan keberadaannya adalah untuk membantu masyarakat (khususnya masyarakat yang kurang dan tidak mampu) dalam memberikan alternatif pendidikan yang dibutuhkan. Sebagai lembaga pendidikan. PKBM diharapkan dapat memberikan proses pendidikan yang efektif dan tepat guna agar para lulusannya kelak dapat memiliki pemahaman ilmu pengetahuan yang dapat bersaing dengan lulusan pendidikan formal.

PKBM memiliki beberapa elemen yang saling berkaitan, antara lain warga belajar (siswa atau peserta yang mengikuti semua kegiatan belajar mengajar atau sasaran), pengelola (pimpinan PKBM yang mengadakan suatu program pembelajaran dan mengurusi administrasi serta menjelaskan cara kerja dalam pencapaian tujuan pembelajaran atau bersifat sama dengan manajerial), tutor (para staf pengajar di PKBM yang bertanggung jawab di dalam proses kegiatan belajar mengajar dalam pencapaian hasil belajar yang maksimal), penilik (orang atau perwakilan dari penyelenggara pendidikan di pemerintahan yang berfungsi memantau jalannya kegiatan belajar mengajar di PKBM), stakeholder/tokoh masyarakat (pemberi sumbangan baik materi ataupun immateri di dalam pelaksanaan program-program di PKBM).

Tujuan PKBM ialah memperluas kesempatan kepada warga masyarakat untuk meningkatkan pengetahuan, keterampilan, dan sikap mental yang diperlukan untuk mengembangkan diri dan memiliki kecakapan hidup. Upaya menyamakan persepsi dan menyelaraskan penyelenggaraan PKBM, dengan ide dasar PKBM sebagai pusat kegiatan pendidikan luar sekolah, PKBM yang tumbuh dan berkembang berdasarkan kepentingan dan kemampuan masyarakat perlu dikembangkan alat ukur kelayakan penyelenggaraan PKBM sebagai media evaluasi dalam pengembangan pelayanan dan peningkatan kinerja tutor.

Peranan PKBM di sini berperan sebagai motor atau penggerak untuk mengadakan perubahan kognitif, afektif, dan psikomotorik peserta didik untuk lebih meningkatkan sumber dayanya sebagai manusia. Tujuan dari perubahan tersebut untuk menciptakan sumber daya manusia yang mandiri agar dapat menciptakan lapangan pekerjaan untuk menambah atau meningkatkan penghasilan dalam pemenuhan kehidupan sehari-hari.

Salah satu PKBM yang ada di Jakarta Utara adalah PKBM Mekar Tanjung di daerah Warakas. PKBM ini memiliki lima program yang sedang dijalankan, salah satunya adalah program pembelajaran Paket $C$. Jumlah peserta didik yang mengikuti program Paket $C$ ini ada 57 orang yang dibagi ke dalam tiga kelas dengan jumlah tutor sebanyak 8 orang yang mengajar di semua kelas. Setiap tutor memiliki teknik dan metode mengajar yang berbeda, akan tetapi mempunyai tujuan yang sama yaitu untuk membelajarkan peserta didik agar mampu menyerap materi yang disampaikan oleh tutor.

Kualitas peserta didik bisa berubah dan meningkat jika diadakan pembelajaran, di mana bahwa belajar adalah proses dari tidak tahu menjadi tahu, tidak bisa menjadi bisa, dan tidak mengerti menjadi mengerti. Hasil dari pembelajaran itu sendiri yakni membuat seseorang menjadi berpengetahuan dan dapat 
menggunakan pengetahuannya dalam kehidupannya sehari-hari. Hasil proses pembelajaran sangat dipengaruhi oleh kinerja tutor. Pembelajaran merupakan jantungnya pendidikan, masalahnya pada saat proses belajar mengajar, peserta didik masih di luar kelas. Keseluruhan masalah tersebut, peneliti memfokuskan pada kinerja tutor dalam mengelola kegiatan pembelajaran pada program Paket C di PKBM Mekar Tanjung.

\section{Identifikasi Masalah}

Berdasarkan dari uraian latar belakang di atas, maka dapat diidentifikasikan masalah-masalah, sebagai berikut.

1. Bagaimana karakteristik tutor Paket C di PKBM Mekar Tanjung, Jakarta Utara?

2. Pembelajaran apa saja yang dilaksanakan di Program Paket $\mathrm{C}$ di PKBM Mekar Tanjung?

3. Apakah teknik dan metode yang digunakan tutor sudah tepat dalam menyampaikan materi kepada peserta didik di PKBM Mekar Tanjung?

4. Bagaimana program pembelajaran dilaksanakan oleh tutor?

5. Bagaimana kinerja tutor dalam mengelola kegiatan pembelajaran pada Program Paket C?

\section{Pembatasan Masalah}

Berdasarkan latar belakang dan identifikasi masalah, maka peneliti membatasi penelitian pada "Kinerja tutor dalam proses pembelajaran pada Program Paket C di PKBM Mekar Tanjung, Jakarta Utara.

\section{Perumusan Masalah}

Berdasarkan pembatasan masalah di atas maka rumusan masalahnya, yaitu "Bagaimana kinerja tutor dalam proses pembelajaran pada Program Paket $C$ di PKBM Mekar Tanjung, Jakarta Utara?".

\section{Kegunaan Penelitian}

Peneliti berharap penelitian ini dapat memberi masukan yang bermanfaat bagi semua pihak, antara lain:

\section{Peneliti}

(1) Pengalaman melakukan penelitian ilmiah

(2) Mengetahui kinerja tutor dalam mengelola kegiatan pembelajaran pada Program Paket $\mathrm{C}$.

\section{Jurusan PLS}

Penelitian ini dapat dijadikan salah satu bahan referensi yang bersifat ilmiah bagi jurusan Pendidikan Luar Sekolah dalam rangka mengembangkan dan meningkatkan mutu pendidikan khususnya dalam mengelola proses pembelajaran Paket $\mathrm{C}$.

3. PKBM

Masukan bagi pengelola PKBM maupun tutor untuk mengetahui cara yang baik dan efektif dalam mengelola proses pembelajaran, khususnya pada Program Paket C.

4. Masyarakat

Gambaran umum untuk masyarakat yang ingin mengetahui mengenai PKBM khususnya proses pembelajaran pada Pogram Paket C.

\section{KAJIAN TEORETIS}

\section{Hakikat Kinerja Tutor}

Secara sederhana, "Kinerja dapat diartikan sebagai kemauan dan kemampuan dalam melakukan pekerjaan". Keterangan lain dijelaskan bahwa "Kinerja dapat bermakna sebagai ukuran dari suatu hasil kerja". Teori Expectory menjelaskan bahwa "Kinerja adalah hasil interaksi antara motivasi (motivation) dengan kemampuan dasar (ability)".

Mengenai kinerja, Kast dan Rosezwerg (1992) mengungkapkan, "Kinerja adalah proses kerja dari seorang individu untuk mencapai tujuan yang relevan". Kast dan Rosezwerg (1992) selanjutnya juga menjelaskan bahwa kinerja sama dengan kesanggupan dan motivasi. Kesanggupan berarti kemampuan untuk berbuat dengan teknik yang sesuai sehingga dapat memberikan indikasi sejauh mana kemungkinan pekerjaan dapat dilakukan, sedangkan motivasi merupakan keinginan untuk melakukan hal-hal yang direncanakan sesuai dengan kemampuan.
Penunjukkan kinerja yang baik diperlukan targettarget penguasaan keterampilan dan kemampuankemampuan tertentu bagi tutor, seperti menguasai kompetensi dasar sebagai tutor, sehingga aspek personal diperlukan adanya tanggung jawab dan kesadaran yang mendalam untuk menciptakan suatu kinerja yang baik, sebab dapat dikatakan bahwa kinerja itu berkaitan dengan kesadaran seseorang terhadap pekerjaan.

Kinerja memiliki makna yang luas, antara lain seperti yang dikemukakan Chourman (1996) bahwa kinerja dapat bermakna, sebagai berikut.

1. Pelaksanaan suatu kegiatan dengan perilaku tertentu

2. Segala sesuatu kegiatan dengan perilaku tertentu

3. Kemampuan menuntaskan suatu pekerjaan secara efisien dan efektif.

4. Kemampuan menetapkan suatu gagasan, ide konsep atau desain rancangan atau desain secara tuntas. 
Kinerja dapat ditinjau dari ciri-ciri konfigurasinya (karakteristik wujudnya), sebagai berikut.

1. Perilaku (behavior) yang mana kinerja dapat diwujudkan, setiap kinerja (performance) dilaksanakan oleh setiap perilaku.

2. Konteks adalah kondisi situasional apa, siapa, di mana, bilamana, mengapa, dan bagaimana perilaku terjadi jika perilaku selalu terjadi dalam suatu konteks.

3. Konsekuensi (dampak) adalah manifestasi kinerja perilaku. Kinerja mempunyai tujuan yang merupakan konsekuensi dari terjadinya perilaku. Jadi, perilaku selalu menimbulkan dampak dan dampak ini adalah tujuan dari suatu kinerja.

4. Kompeten atau mampu adalah suatu wujud perilaku yang dapat bernilai secara efisien dan efektif, artinya berhasil guna dengan pengorbanan atau biaya yang rendah dan dengan hasil yang optimal.

5. Tuntas (accomplishment) adalah penyelesaian secara utuh menyeluruh seluruh perilaku yang dilaksanakan sehingga dampak (tujuan perilaku) tercapai secara baik (a valuable accomplishment). Jadi, setiap kinerja yang menimbulkan dampak yang tuntas sifatnya disebut sebagai suatu kinerja yang baik (a valuable performance).

\section{Pengukuran Kinerja}

Pengukuran kinerja adalah proses sistematis dan berkesinambungan untuk menilai keberhasilan dan kegagalan pelaksanaan kegiatan sesuai dengan program, kebijakan, sasaran, dan tujuan yang telah ditetapkan dalam mewujudkan visi dan misi satuan organisasi/kerja. Pengukuran kinerja merupakan hal yang penting dalam manajemen program secara keseluruhan karena kinerja yang dapat diukur akan mendorong pencapaian kinerja tersebut. Pengukuran kinerja yang dilakukan secara berkelanjutan memberikan umpan balik penting dalam upaya perbaikan secara terus menerus dan mencapai keberhasilan di masa mendatang. Melalui pengukuran kinerja diharapkan satuan organisasi/kerja dapat mengetahui kinerja dalam suatu periode tertentu. Adanya suatu pengukuran kinerja maka kegiatan dan program satuan organisasi/kerja dapat diukur dan dievaluasi. Pengukuran kinerja, setiap instansi dapat dibandingkan dengan instansi yang sejenis, sehingga penghargaan dan tindakan disiplin dapat dilakukan secara lebih objektif. Ini berarti bahwa pengukuran kinerja penting peranannya sebagai alat manajemen.

Pengukuran kinerja merupakan suatu proses mencatat dan mengukur pencapaian pelaksanaan kegiatan dalam arah pencapaian sasaran, tujuan, misi, dan visi melalui hasil-hasil yang ditampilkan beberapa produk, jasa, ataupun proses pelaksanaan suatu kegiatan.
Beberapa definisi performance measures yang diberikan oleh para peneliti seperti yang dikutip oleh Rivai dan Sagala (2009) sebagai berikut.

1. Performance measures are characteristic of outputs that are identified for purpose of evaluation (Euske,1984)

2. Performance indicator is a tool to compare actual results with a preset target and to measure the extent of any deviations (Fortuin, 1988).

3. Performance measures are the numerical or quantitative indicators that show how well each objective is being met (Princhard, 1991)

4. Performance measures are the vital signs of the organization which quantify how well the activities within a process or the outputs of a process achieve a specified goal (Hronec, 1993)

5. Performance indicator are quantified data which measure the eficiency of an activity or a set of activity of a function in the process to reach the objective (Doumeingts, 1995)

6. Performance measure is a quantitative description of the quality products or service or system (Trade, 1997).

Jadi dapat diambil kesimpulan, sebagai berikut.

1. Performance measures (mengukur kinerja) adalah matrik yang menunjukkan efisiensi dan atau efektivitas dari suatu action.

2. Performance measurement (pengukuran kinerja) adalah suatu proses untuk mengukur efisiensi dan atau efektivitas dari suatu action.

3. Performance measurement system (sistem pengukuran kinerja) adalah sekumpulan matrik dan prosedur yang terstruktur untuk mengetahui efektivitas dan efisiensi.

\section{Pengertian Tutor}

Tutor merupakan pengajar di dalam sebuah PKBM. Dalam hal ini, berhasil tidaknya proses belajar mengajar di PKBM sangat dipengaruhi oleh peran aktif para tutor. Demi kelancaran proses belajar mengajar di sebuah PKBM, setiap tutor hendaknya memiliki teknik dan menggunakan metode mengajar yang dapat menyiasati warga belajar untuk merespon setiap stimulus yang disampaikan di dalam kegiatan belajar mengajar yang sedang berlangsung. Bentuk sistem mengajar inilah yang nantinya akan disebut sebagai kinerja tutor, baik hasilnya mengarah ke arah yang menunjang keberhasilan warga belajar maupun yang memang tidak mengubah apapun atau dapat dikatakan nihil hasil proses pembelajarannya.

Kemampuan tutor (ability) dapat dinilai dari kemampuannya dalam penguasaan metode dan teknik mengajar yang diterapkannya, hal ini dapat disebut juga bahwa kinerja tutor dapat dilihat dari wawasan tutor 
dan pemahaman tutor tentang tugas pokok yang diembannya, apakah sudah sesuai atau belum, maka dapat disimpulkan bahwa kinerja tutor itu sudah baik, cukup ataupun dirasa masih kurang sesuai dengan tugas pokok tutor yang seharusnya.

\section{Hakikat pembelajaran}

\section{Pengertian Pembelajaran}

Belajar menurut Hakim (2000) adalah "Suatu proses perubahan di dalam kepribadian manusia dan perubahan tersebut ditampakkan dalam bentuk peningkatan kualitas dan kuantitas tingkah laku seperti peningkatan kecakapan, pengetahuan, sikap, kebiasaan, pemahaman, keterampilan, daya pikir, dan kemampuan".

Belajar adalah suatu proses yang kompleks yang terjadi pada diri setiap orang sepanjang hidupnya. Proses belajar itu terjadi karena adanya interaksi antara seseorang dengan lingkungannya. Belajar dapat terjadi kapan saja dan di mana saja. Salah satu pertanda bahwa seseorang itu telah "belajar adalah adanya perubahan tingkah laku pada diri orang itu yang mungkin disebabkan oleh terjadinya perubahan pada tingkat pengetahuan, keterampilan atau sikapnya".

Belajar adalah suatu aktivitas mental/psikis yang berlangsung dalam interaksi aktif dengan lingkungannya yang menghasilkan perubahan-perubahan dalam pengetahuan pemahaman, keterampilan, dan nilai sikap. Perubahan itu bersifat secara relatif konstan dan berbekas".

Istilah pembelajaran muncul secara bertahap dan perkembangannya disebabkan perhatian terhadap anak didik dalam usaha pendidikan dan pengajaran. Awalnya istilah "mengajar" sangat popular sebagai suatu upaya pendidik menyampaikan pengetahuan kepada anak didik. Para ahli mulai menyadari sesungguhnya dalam pendidikan dan pengajaran, semua upaya dilakukan untuk kepentingan siswa dan bukan untuk kepentingan guru (teacher oriented), maka istilah mengajar diganti dengan proses "belajar mengajar".

Kemudian dirasakan bahwa istilah belajar mengajar tidak tepat karena seperti terbagi menjadi dua kegiatan, lalu muncul istilah baru yang lebih tepat yaitu "membelajarkan" atau "pembelajaran", karena "mengajar pada hakikatnya merupakan upaya pendidik untuk membangkitkan yang memiliki pengertian membuat seseorang untuk bangkit, artinya memberikan dorongan kepada peserta didik untuk mau belajar". Belajar dan pembelajaran adalah dua kata yang tak dapat dipisahkan, karenanya pembelajaran dapat diartikan sebagai "pembimbingan terhadap siswa agar secara sadar dan terarah berkeinginan untuk belajar dan memperoleh hasil belajar sebaik-baiknya, sesuai dengan keadaan dan kemampuan siswa yang bersangkutan". Setiap individu pasti pernah mengalami dan menjalani proses belajar baik itu disadari ataupun tidak, karena kegiatan belajar merupakan kegiatan yang terjadi pada semua orang tanpa mengenal batas usia yang berlangsung seumur hidup baik itu di lingkungan formal atau nonformal.

Pembelajaran memiliki makna yang sama dengan membelajarkan yang mengandung arti sebagai proses membuat seseorang menjadi belajar. "Pembelajaran adalah suatu kombinasi yang tersusun meliputi unsur-unsur manusia, material, fasilitas, perlengkapan, dan prosedur yang saling mempengaruhi untuk mencapai tujuan pembelajaran". Sadiman mengartikan "pembelajaran yang menekankan pada proses belajar siswa, sehingga usaha-usaha yang terencana dalam memanipulasi sumber-sumber belajar agar terjadi proses belajar dalam diri siswa disebut pembelajaran".

Pengertian pembelajaran menurut Undangundang RI Nomor 20 tahun 2003 tentang sistem Pendidikan Nasional Bab 1 Pasal 1 Ayat 20, "pembelajaran adalah proses interaksi peserta didik dengan pendidik dan sumber belajar pada suatu lingkungan belajar".

Berdasarkan pengertian di atas, maka dapat disimpulkan bahwa pengertian dari pembelajaran adalah upaya-upaya yang dilakukan oleh pengajar dalam membelajarkan peserta didik dengan menggunakan komponen-komponen belajar untuk mencapai tujuan yang telah ditentukan dalam proses kegiatan belajar mengajar. Jadi, pembelajaran yang dimaksud di sini adalah upaya-upaya yang dilakukan oleh pendidik untuk mencapai tujuan pembelajaran sesuai dengan yang telah ditentukan.

\section{Proses Pembelajaran}

Aktivitas pembelajaran bukan hanya merupakan proses penyampaian dan penerimaan informasi tetapi juga memberikan pengelaman belajar kepada peserta didik. Pengalaman ini harus memberikan dorongan untuk mengubah tingkah laku peserta didik seperti yang diinginkan.

Pembelajaran terjadi apabila rangsangan dilakukan oleh tutor yang akan menyebabkan perubahan tingkah laku. Untuk melaksanakan proses ini, tutor dapat menggunakan berbagai pendekatan, dan metode yang sesuai dengan keperluan peserta didik.

Untuk mencapai kompetensi tertentu, pengelolaan pembelajaran dapat menggunakan berbagai pendekatan dan metode. Kelompok belajar bersama tutor dapat menggalakkan peserta didik yang mempunyai berbagai keunggulan berinteraksi dan bekerjasama untuk menguasai suatu konsep atau 
kemahiran, bukan saja untuk diri sendiri tetapi juga untuk rekan-rekan yang lain, serta memotivasi semua peserta didik. Tutor dapat membantu peserta didik dengan menggunakan berbagai pendekatan dan metode yang sesuai dengan keperluan peserta didik.

Urutan proses pembelajaran dikelompokkan ke dalam tiga tahapan pokok, yaitu tahap pendahuluan, penyajian materi, serta evaluasi dan tindak lanjut. Ketiga tahapan ini harus ditempuh pada setiap melaksanakan pembelajaran. Apabila satu tahap ditinggalkan, maka tidak dapat dikatakan sebagai proses pembelajaran yang baik.

\section{1) Tahap Pendahuluan}

Tahap pendahuluan yang dikenal dengan tahap persiapan merupakan tahapan yang ditempuh tutor pada saat memulai pembelajaran. Ada beberapa kegiatan yang dapat dilakukan oleh tutor pada tahap pendahuluan ini, yaitu membangkitkan motivasi peserta didik, menjelaskan tujuan pembelajaran, melakukan pengulangan pelajaran yang lalu, menghubungkan dengan pelajaran yang sekarang serta memberitahu kegunaan bahan pelajaran yang berlangsung, dan menempatkan pokok masalah saat pelajaran.

Hal ini perlu dilakukan oleh tutor karena jika peserta didik tidak mengetahui apa tujuan mempelajari materi pelajaran yang akan dipelajari, akan beranggapan tidak ada gunanya dan sia-sia saja mempelajari materi jika tidak ada tujuan yang ingin dicapai. Jika kegiatan pendahuluan diterapkan keseluruhan, maka dapat dikatakan peserta didik telah memiliki gambaran menyeluruh tentang materi yang akan dipelajarinya yang berkaitan dengan pengalaman sehari-hari, bermotivasi tinggi untuk mempelajari materi pelajaran dan mungkin dapat mengorganisasikan kegiatan belajar dengan baik. 2) Tahap Penyajian Materi

Tahap penyajian materi dikatakan sebagai tahap inti, yaitu tahapan memberikan bahan pelajaran yang disusun tutor sebelumnya. Langkah-langkah yang dilakukan pada tahap penyajian materi adalah penjelasan materi, memberikan kesempatan pada peserta didik untuk terlibat secara efektif, memberi penguatan, mengorganisir waktu, peserta didik, dan fasilitas.

3) Tahap Evaluasi dan Tindak Lanjut

Tahapan ketiga adalah evaluasi dan tindak lanjut. Tujuan tahapan ini adalah untuk mengetahui tingkat keberhasilan dari tahapan penyajian materi. Kegiatan yang dilakukan pada tahapan ini adalah memeriksa hasil pekerjaan peserta didik, menyimpulkan pelajaran yang telah dipelajari, memberi tugas kepada peserta didik, dan memberi soal-soal kepada peserta didik untuk pekerjaan rumah.

\section{Pengertian PKBM (Pusat Kegiatan Belajar Masyarakat)}

"PKBM (Pusat Kegiatan Belajar Masyarakat) merupakan instansi pendidikan nonformal yang dimiliki dan dikelola oleh masyarakat atau organisasi masyarakat, organisasi sosial masyarakat atau organisasi keagamaan". Pemerintah berperan sebagai fasilitator.

PKBM bisa juga diartikan sebagai tempat belajar dari masyarakat, oleh masyarakat dan untuk masyarakat dalam rangka usaha meningkatkan pengetahuan, keterampilan, sikap, hobi, bakat serta minat warga masyarakat yang bertitik tolak dari kebermaknaan dan kebermanfaatan program bagi warga belajar dengan menggali dan memanfaatkan potensi Sumber Daya Manusia (SDM) dan Sumber Daya Alam (SDA) yang ada di lingkungannya.

PKBM didirikan untuk pemberdayaan masyarakat; dalam aspek ekonomi, budaya, dan sosial. PKBM adalah tempat atau pusat belajar masyarakat; oleh, dari, dan untuk masyarakat yang netral dan fleksibel. PKBM sebagai lembaga pendidikan nonformal, yang tersebar di berbagai desa dan kota, melayani berbagai program pendidikan nonformal, yang diantaranya adalah pendidikan anak usia dini, keaksaraan fungsional, kursus, dan Pendidikan Kesetaraan Paket A, Paket B, dan Paket C

\section{Pengertian Paket $C$}

Pendidikan nonformal (PNF) diselenggarakan bagi warga masyarakat yang memerlukan layanan pendidikan yang berfungsi sebagai pengganti, penambah, dan/atau pelengkap pendidikan formal dalam rangka mendukung pendidikan sepanjang hayat. PNF juga berfungsi untuk mengembangkan potensi peserta didik dengan penekanan pada penguasaan pengetahuan dan keterampilan fungsional. PNF meliputi pendidikan kecakapan hidup, pendidikan anak usia dini, pendidikan kepemudaan, pendidikan pemberdayaan perempuan, pendidikan keaksaraan, pendidikan keterampilan dan pelatihan kerja, pendidikan kesetaraan, serta pendidikan lain yang ditujukan untuk mengembangkan kemampuan peserta didik. Satuan PNF terdiri atas lembaga kursus, lembaga pelatihan, kelompok belajar, pusat kegiatan belajar masyarakat, dan majelis taklim.

Pendidikan kesetaraan adalah pendidikan nonformal dengan standar kompetensi lulusan yang sama dengan sekolah formal, tetapi konten, konteks, metodologi dan pendekatan untuk mencapai standar kompetensi tersebut lebih memberikan konsep-konsep terapan, tematik, induktif yang terkait dengan permasalahan lingkungan dan melatih kehidupan 
berorientasi kerja atau berusaha mandiri.

Tertuang dalam Undang-Undang RI No. 20 tahun 2003 tentang sistem pendidikan nasional "Pendidikan kesetaraan adalah program pendidikan nonformal yang menyelenggarakan pendidikan umum setara SD, SMP, dan SMA yang mencakup Program Paket A,B, dan C".

Paket $C$ sebagai salah satu program pendidikan kesetaraan bertujuan sebagai pengganti pendidikan formal setara SMA yang oleh karena berbagai fleksibilitas dalam menyelenggarakan kegiatan pembelajarannya.

Berdasarkan petunjuk teknis yang diterbitkan Dirjen Pendidikan Luar Sekolah dan Pemuda Depdiknas tahun 2000 maka dalam kegiatan proses belajar mengajar Paket $C$ setara SMA, sebagai berikut.

1. Elemen masukan yaitu warga belajar yang memenuhi persyaratan: Lulusan Paket B setara SMP, lulusan SMP, dan putus SMA.

2. Elemen proses pada PKBM di Paket $C$ setara SMA berupa :

a. Faktor instrumental

1. Pendidik atau tutor

2. Kurikulum atau program belajar

3. Materi atau bahan ajar

4. Metode

5. Sarana

6. Waktu

7. Sistem evaluasi

b. Faktor lingkungan

1. Faktor fisik: tempat belajar

2. Faktor sosial: teman dan keluarga masyarakat

3. Faktor psikologis: motivasi belajar

3. Elemen keluaran pada kegiatan belajar mengajar di Paket $\mathrm{C}$ adalah hasil belajar yang diperoleh warga belajar berupa pengetahuan, keterampilan, dan sikap.

Program Paket C setara SMA berfungsi memberikan layanan yang berjenjang melalui jalur pendidikan nonformal bagi warga masyarakat yang tidak atau belum mendapatkan pelayanan pendidikan pada jenjang SLTA.

Paket $\mathrm{C}$ memberikan peluang pada masyarakat yang telah menyelesaikan program Paket B setara SLTP dan telah menyelesaikan pendidikan setingkat SLTP serta lulusan MTs yang tidak melanjutkan ke SLTA atau putus sekolah SLTA. Fungsi berikutnya memberikan bekal keterampilan untuk bekerja atau usaha mandiri.

Program Paket C setara SMA dapat diselenggarakan oleh Pusat Kegiatan Belajar Masyarakat (PKBM), Sanggar Kegiatan Belajar (SKB), Masjid, Gereja, Balai Desa, Pondok Pesantren, Kantor
Organisasi Kemasyarakatan, dan tempat-tempat lainnya yang layak digunakan untuk kegiatan belajar mengajar.

\section{Kerangka Berpikir}

Pendidikan merupakan kebutuhan dalam kehidupan sehari-hari bagi masyarakat. Kebutuhan akan pendidikan dapat dilihat dari berbagai lingkup kehidupan, mulai dari keseharian di dalam lembaga keluarga sampai pada kebutuhan untuk menunjang perekonomian individu. Pendidikan merupakan kata kunci dalam menjalankan aktivitas untuk meningkatkan kesejahteraan masyarakat, baik secara personal maupun kelompok. Secara singkat, dapat dikatakan pendidikan memiliki peranan yang sangat penting dalam keberlangsungan hidup seseorang maupun golongan.

Fungsi pendidikan memiliki pandangan untuk mengembangkan kemampuan dan membentuk potensi peserta didik agar mampu bersaing dalam peradaban yang bermartabat serta untuk mencerdaskan kehidupan bangsa yang beriman bertakwa, dan inovatif. Terkait Pendidikan Luar Sekolah memiliki tujuan untuk menciptakan manusia yang diharapkan memiliki daya guna. Pernyataan tersebut dapat dilihat dari memberikan keterampilan hidup (life skill) yang memang memiliki ranah untuk meningkatkan taraf hidup secara personal ataupun diluar personal dari individu tersebut. Pelaksanaan pendidikan terdiri dari pendidikan formal dan nonformal. Pendidikan formal seperti yang dikenal memiliki jenjang yang pasti, pelaksanaan waktu belajar terikat, kurikulum ditetapkan secara nasional, sedangkan pendidikan nonformal sebaliknya. Salah satu bentuk penyelenggaraan pendidikan nonformal adalah PKBM (Pusat Kegiatan Belajar Masyarakat).

PKBM adalah sebuah satuan Pendidikan Luar Sekolah yang memberikan keterampilan hidup dalam pembelajarannya. PKBM merupakan salah satu satuan pendidikan alternatif selain pendidikan formal. Keberadaan PKBM sendiri merupakan sebuah bentuk pendidikan yang memang berbasis kepada masyarakat. Mulai dari kurikulum sampai kepada proses pembelajarannya.

Dilihat kesesuaian dari pernyataan di atas maka dapat dirumuskan pada kegiatan pembelajaran yang dikelola oleh PKBM. Perumusan ini diawali mulai dari karakteristik tutor dan kinerja tutor sebagai tenaga pengajar dalam proses transfer ilmu. Kemudian berlanjut kepada pembelajaran yang dilaksanakan di PKBM khususnya PKBM Mekar Tanjung pada Program Paket C. Dalam proses pembelajaran, seorang tutor harus melakukan perencanaan pembelajaran, pada 
pelaksanaan pembelajaran dan dapat menjalin hubungan antarpribadi tutor dengan warga belajar. Proses kegiatan pembelajaran di PKBM Mekar Tanjung dilihat dari kesiapan tutor dalam melakukan perencanaan, dalam pelaksanaan berupa rancangan pembelajaran dan silabus sebagai pedoman pembelajaran. Komponen pembelajaran terkait dengan hubungan pribadi tutor dengan warga belajar tidak tercipta atau terjalin dengan baik, ini dapat dilihat karena masih adanya beberapa warga belajar yang kurang mengenal baik tutornya.

Proses pelaksanaan pembelajaran juga dapat dilihat dari kemampuan tutor menguasai teknik dan metode pembelajaran yang dilaksanakan, agar hasil belajar dapat lebih maksimal. Pemaparan dari hasil yang telah dilaksanakan nantinya akan dapat menghasilkan penggambaran mengenai kinerja tutor pada proses pembelajaran yang dilaksanakan oleh PKBM Tanjung Mekar pada Program Paket C. Tujuannya adalah untuk melihat kinerja tutor pada Program Paket C PKBM Mekar Tanjung yang lebih dikhususkan kepada kebermanfaatan bagi peneliti dan PKBM sebagai bentuk penggambaran untuk melihat perkembangan kinerja tutor dalam menunjang kemajuan PKBM Mekar Tanjung. Sangatlah penting untuk mengetahui penggambaran mengenai kinerja tutor pada proses pembelajarannya.

\section{METODOLOGI PENELITIAN}

\section{Tujuan penelitian}

Tujuan diadakan penelitian di PKBM Mekar Tanjung adalah untuk memperoleh data empiris, gambaran dan informasi yang tepat berdasarkan data yang akurat, benar dan dapat dipercaya. Data-data yang diperlukan seputar kinerja tutor dalam mengelola kegiatan pembelajaran pada Program Paket C di PKBM Mekar Tanjung.

Tempat dan waktu penelitian

1. Tempat peneitian

Penelitian ini dilaksanakan di PKBM Mekar Tanjung yang bertempat di JI. Warakas VII, Jakarta Utara.

2. Waktu Peneitian

Penelitian ini dilakukan sejak tanggal 15 Februari 2010 sampai akhir penelitian 14 Mei 2010.

\section{Metode Penelitian}

Metode penelitian yang digunakan dalam penelitian ini adalah metode deskriptif dengan pendekatan kualitatif. Pendekatan deskriptif kualitatif didefinisikan sebagai penggambaran situasi yang sebenarnya tentang suatu objek, gejala, atau keadaan dari hasil temuan di lapangan serta memahaminya sehingga mendapatkan suatu gambaran atau informasi yang tepat berkaitan dengan masalah penelitian tersebut (Arikunto, 2006).

Penelitian ini bertujuan untuk menggambarkan suatu kegiatan dan keadaan secara cermat dan terperinci mengenai kinerja tutor dalam mengelola kegiatan pembelajaran pada Program Paket C di PKBM Mekar Tanjung dengan terlebih dahulu menganalisis kejadiannya untuk kemudian dipertimbangkan dengan teori yang ada atau standar yang telah ditentukan.

\section{Populasi dan Sampel Penelitian}

\section{Populasi}

Dalam penelitian ilmiah diperlukan sumber data yang berkaitan dengan masalah penelitian yang dapat memberikan keterangan yang dibutuhkan. Sumber data dalam suatu penelitian disebut dengan populasi. Populasi juga merupakan keseluruhan objek penelitian yang terdiri dari manusia, benda, hewan, tumbuhan, gejala, nilai tes, atau peristiwa sebagai gambaran data yang memiliki karakteristik tertentu di dalam suatu penelitian.

Berdasarkan penjelasan di atas, maka populasi dari penelitian kinerja tutor dalam mengelola kegiatan pembelajaran pada Program Paket C di PKBM Mekar Tanjung adalah seluruh warga belajar paket $C$.

\section{Sampel}

Sampel adalah "Sebagian atau wakil populasi yang diteliti" (Arikunto, 2006). Sampel juga sering didefinisikan sebagai "Bagian dari populasi sebagai contoh yang diambil dengan menggunakan cara-cara tertentu peneliti bermaksud mereduksi objek penelitian sebagai akibat dari besarnya jumlah populasi sehingga harus meneliti sebagian saja dari populasi".

\section{Teknik Pemilihan Informan}

Informan adalah orang yang dimanfaatkan untuk memberikan informasi tentang situasi dan kondisi latar penelitian. Teknik pemilihan informan dilakukan dengan menggunakan teknik purposive sampling, yaitu teknik yang dilakukan dengan cara mengambil subjek bukan berdasarkan atas strata, random atau daerah tetapi didasarkan atas adanya tujuan tertentu. Teknik ini biasanya dilakukan karena beberapa pertimbangan, misalnya alasan keterbatasan waktu, tenaga, dan dana 
sehingga tidak dapat mengambil sample yang besar dan jauh.

Teknik pemilihan informan berdasarkan atas informan yang diinginkan mengenai kinerja tutor dalam mengelola kegiatan pembelajaran pada Program Paket $C$ di PKBM Mekar Tanjung, maka informan berjumlah 10 orang warga belajar Paket $\mathrm{C}$.

\section{Teknik Pengumpulan Data}

Teknik pengumpulan data ialah cara-cara yang digunakan oleh peneliti untuk mengumpulkan data. Penelitian ini dilakukan melalui langkah-langkah, sebagai berikut.

\section{Pengamatan}

Peneliti dalam penelitian ini berperan sebagai pengamat yang melihat, mendengar, dan mencatat segala peristiwa yang terjadi di depan mata. Peneliti mengamati kinerja tutor dalam mengelola kegiatan pembelajaran pada Program Paket C di PKBM Mekar Tanjung. Menurut Suparlan (1996) dalam menggunakan metode pengamatan ada delapan hal penting yang harus diperhatikan, yaitu.

a. Ruang atau tempat. Setiap kegiatan meletakan sesuatu benda, orang dan hewan tinggal, pasti membutuhkan ruang atau tempat

b. Pelaku. Peneliti mengamati ciri-ciri pelaku yang ada di ruang atau tempat.

c. Kegiatan. Pengamatan dilakukan pelaku-pelaku yang melakukan kegiatan-kegiatan di ruang, sehingga menciptakan interaksi antara pelaku yang satu dengan yang lainnya dalam ruang dan waktu.

d. Benda-benda atau alat-alat. Peneliti mencatat semua benda atau alat-alat yang digunakan oleh pelaku untuk berhubungan secara langsung atau tidak langsung dengan kegiatan pelaku.

e. Waktu. Peneliti mencatat setiap tahapan-tahapan waktu dari sebuah kegiatan

f. Peristiwa. Peneliti mencatat setiap peristiwaperistiwa yang terjadi selama kegiatan pelaku.

g. Tujuan. Peneliti mencatat tujuan dari setiap kegiatan yang ada.

h. Perasaan. Peneliti juga perlu mencatat perubahanperubahan yang terjadi pada setiap peserta atau pelaku kegiatan, baik dalam bahasa verbal maupun non verbal yang berkaitan dengan perasaan atau emosi

\section{Wawancara Mendalam (In Depth Interview)}

Wawancara adalah suatu cara pengumpulan data yang digunakan untuk memperoleh informasi langsung dari sumbernya. Wawancara digunakan bila ingin mengetahui hal-hal dari responden secara lebih mendalam serta jumlah responden sedikit.

Wawancara yang digunakan adalah wawancara mendalam yakni dilakukan untuk memperoleh informasi dan data yang diperlukan secara mendalam yang diperoleh dari para informan. Instrumen dalam penelitian ini menggunakan pedoman wawancara mendalam untuk menekan pada pokok-pokok atau alur pembicaraan mengenai hal-hal yang perlu ditanyakan kepada informan. Pedoman wawancara ini berisikan pertanyaan terbuka yang nantinya akan memberikan keleluasaan bagi informan untuk mengemukakan pendapatnya secara bebas kepada peneliti. Teknik wawancara juga digunakan untuk memperolah keterangan-keterangan yang lebih akurat, yang tentunya berisikan informasiinformasi tentang variabel yang akan diteliti.

3. Catatan lapangan

Moleong (2008) mengemukakan catatan lapangan adalah "Catatan tertulis tentang apa yang didengar, dilihat, dialami, dan dipikirkan dalam rangka pengumpulan data dan refleksi terhadap data dalam penelitian kualitatif". Catatan Iapangan sangat diperlukan dalam melakukan suatu penelitian kualitatif, karena penemuan dari suatu pengetahuan atau teori itu harus didukung oleh data konkret dan bukan berasal dari ingatan. Penentuan kepercayaan dan keabsahan data, semuanya harus berdasarkan atas data yang terdapat dalam catatan lapangan. Catatan lapangan dilakukan saat peneliti berada di PKBM Mekar Tanjung Jakarta Utara dan proses pembelajaran Paket $\mathrm{C}$ masih berlangsung.

\section{Penggunaan dokumentasi}

Moleong (2008) mendefinisikan dokumen sebagai "Setiap bahan tertulis ataupun film". Dokumentasi yang dipergunakan untuk memperkuat data dari hasil wawancara dengan informan penelitian ini antara lain berupa foto kegiatan, brosur dari PKBM Mekar Tanjung dan laporan kegiatan yang dilakukan selama proses pengumpulan data di lapangan. Penggunaan dokumen ini bertujuan untuk menemukan dokumen yang relevan dengan kebutuhan penelitian sehingga dapat digunakan untuk argumen-argumen yang tentunya dapat dipertanggungjawabkan.

\section{Instrumen penelitian}

Instrumen penelitian yang digunakan adalah pedoman wawancara dan pedoman observasi. Metode wawancara digunakan dalam penelitian ini untuk mendapatkan data-data tentang pelaksanaan program yang meliputi aspek perencanaan, pelaksanaan, hasil, dan pengaruh pelaksanaan program, pengumpulan data dengan mengadakan tanya jawab kepada warga belajar tentang hal-hal yang berhubungan dengan penelitian ini. Sedangkan observasi digunakan untuk mengamati dan mencatat terhadap gejala atau kejadian yang terjadi pada saat pelaksanaan program. 


\section{Uji Keabsahan Data}

Data dan informasi yang telah didapatkan akan diuji tingkat keabsahannya melalui derajat kepercayaan. Peneliti menggunakan teknik triangulasi untuk mengetahui derajat kepercayaan data dan informasi yang didapatkan dari tempat penelitian, yang menurut Sugiyono (2006) dikatakan sebagai teknik pengumpulan data yang bersifat menggabungkan dari berbagai teknik pengumpulan data dan sumber data yang telah ada.

Teknik triangulasi digunakan peneliti untuk membandingkan data hasil pengamatan dengan hasil wawancara, membandingkan data dan informasi yang didapat dari warga belajar, membandingkan keadaan perspektif pendidik dengan berbagai pendapat dan pandangan informan, serta membandingkan hasil wawancara dengan isi suatu dokumen yang berkaitan. Teknik Analisis Data

Teknik analisis yang digunakan dalam penelitian ini adalah analisis deskriptif kualitatif, berdasarkan data yang diberikan kepada responden. Analisis data menurut Muhadjir (2000) ialah "Upaya mencari dan menata catatan hasil observasi, wawancara dan lainnya untuk meningkatkan pemahaman peneliti tentang kasus yang diteliti dan menyajikannya sebagai temuan bagi orang lain". Proses analisis dimulai dari penelaahan seluruh data yang didapatkan serta melakukan pengolahan data dan membuat rangkuman di mana data utama, proses, dan pertanyaan penting tetap ada.

Teknik menganalisis data dalam penelitian ini dibagi dalam dua tahap (Milles dan Hubberman, 1992) yaitu.

1. Analisis selama pengumpulan data.

a. Mengembangkan catatan lapangan

b. Mengkategorikan data dan memberi kode pada data

c. Memasukan data ke dalam analisis

d. Mengembangkan pertanyaan untuk mengumpulkan data selanjutnya.

2. Analisis setelah data terkumpul

a. Mengumpulkan data dan memberi nomor secara kronologis sesuai dengan waktu pengumpulan.

b. Meneliti ulang data dan mengelompokan ke dalam satu format kategorisasi dan klasifikasi data sesuai dengan kodenya.

c. Memaparkan data yang telah dianalisis dengan fokus masing-masing penelitian.

d. Penarikan beberapa kesimpulan.

Data yang dikumpul disajikan dalam bentuk tabulasi agar data lapangan dapat tampak ringkas dan tersusun dalam satu tabel, serta data dapat dibaca dengan mudah dan maknanya pun dapat segera diketahui.

\section{HASIL PENELITIAN}

Peranan PKBM Mekar Tanjung sebagai penyelenggara proses pembelajaran dalam konteks pendidikan nonformal (PLS) dapat dikatakan sebagai motor atau penggerak untuk mengadakan perubahan baik kognitif, afektif, dan psikomotorik peserta didik untuk lebih meningkatkan sumber dayanya sebagai manusia.

\section{Profil Pendidik dan Tenaga Kependidikan}

PKBM Mekar Tanjung memiliki 14 pendidik. Para pendidik tidak hanya mengajar dalam satu program pembelajaran, tetapi merangkap di beberapa program pembelajaran, misalnya seperti satu orang tutor mengajar di Paket $A$ dan paket $B$. Untuk Paket $C$ sendiri mempunyai tutor sebanyak 8 orang. Masing-masing orang mengajarkan mata pelajaran yang berbeda.

Tutor di PKBM Mekar Tanjung memiliki kemampuan keilmuan yang diperlukan untuk kegiatan pembelajaran sesuai dengan tujuan pendidikan, selain itu, juga harus bersedia bekerja walau dengan penghasilan yang kurang memadai. Tutor yang memiliki kinerja yang baik dapat dilihat dari adanya suatu produk yang dihasilkan oleh tutor tersebut, produk dalam hal ini adalah lulusan warga belajar yang berkualitas.

PKBM Mekar Tanjung yang mengelola Paket $\mathrm{C}$ dalam meningkatkan mutu pembelajaran, ketua berusaha meningkatkan kinerja tutornya pada proses pembelajaran setiap mata pelajaran. Kinerja tutor khususnya dalam hal ini merupakan penunjang proses pembelajaran Paket $C$, fasilitas pendukung pendidikan yang memadai, jika tidak dibarengi dengan keberadaan tutor yang memiliki kinerja yang cukup baik terhadap proses pembelajaran, bukan tidak mungkin pembelajaran yang dilakukan hasilnya tidak akan optimal.

Realitanya sampai saat ini masih banyak tutor yang hanya memberikan ilmu pengetahuan yang dimilikinya pada warga belajar tanpa adanya perencanaan yang matang, sehingga berdampak pada keberhasilan dalam proses pembelajaran di kelas, seperti tidak membuat RPP permata pelajaran. Permasalahan ini kendalanya diduga karena kurangnya supervisi dari ketua maupun instansi yang terkait terhadap peningkatan kualitas kinerja tutor yang dibatasi 
pada kemampuan dalam hal merencanakan pembelajaran, melaksanakan pembelajaran serta melakukan evaluasi terhadap kegiatan proses pembelajaran yang telah berlangsung. Usaha peningkatan mutu pembelajaran memerlukan tutor yang mampu meningkatkan pengetahuannya dan menyadari akan pertumbuhan dan pengembangan profesi yang dijalaninya. Bukan hanya itu tutor juga harus dapat menguasai kemampuan berkomunikasi dengan baik sehingga dapat lebih mencairkan suasana yang kondusif dalam pembelajaran di kelas dan dapat memberikan motivasi belajar pada setiap warga belajarnya.

Tenaga kependidikan di PKBM Mekar Tanjung ada tiga orang yang terdiri dari ketua, bendahara, dan sekretaris. Selain sebagai tenaga kependidikan di PKBM, juga bertindak sebagai tutor pada setiap program pembelajaran yang ada di PKBM.

\section{Kurikulum dan Pengembangannya}

Kurikulum yang digunakan di PKBM Mekar Tanjung adalah sesuai dengan kurikulum yang dikeluarkan oleh Kementerian Pendidikan Nasional, namun dalam pelaksanaannya setiap tutor mempunyai hak untuk menggunakan kurikulum tambahan atau media lain yang dianggap perlu dan sesuai dengan kebutuhan peserta didik.

Materi yang diberikan kepada peserta didik boleh dari buku atau sumber manapun yang penting sesuai dengan kurikulum dan kebutuhan peserta didik. Mengapa ada kurikulum yang disesuaikan dengan kebutuhan peserta didik? Karena dalam pendidikan non formal peserta didik terdiri dari berbagai latar belakang maka tidak dapat disamaratakan dan juga di dalam pelaksanaan proses pembelajaran pendekatan yang lebih banyak digunakan adalah pendekatan andragogi atau pendekatan orang dewasa. Tutor berfungsi sebagai pendamping dan teman dalam proses pembelajaran bukan sebagai guru yang bertugas hanya menggurui dan mentransfer ilmu saja.

\section{Sumber materi}

Materi yang diberikan oleh pendidik di PKBM Mekar Tanjung disesuaikan dengan kebutuhan peserta didik dan mengacu pada kurikulum yang dikeluarkan oleh Kementerian Pendidikan Nasional. Materi yang digunakan dapat bersumber dari buku-buku pelajaran, buku bacaaan, internet atau bersumber dari mana saja asal sesuai dengan kebutuhan.

Materi juga bisa menggunakan peristiwaperistiwa yang sedang terjadi pada saat itu. Ini dimaksudkan agar peserta didik tidak tertinggal oleh berita-berita yang sedang terjadi di Indonesia, tetapi juga lebih bisa up to date, sehingga tidak ketinggalan zaman.

\section{Kinerja Tutor}

\section{a. Penguasaan kelas}

Proses kegiatan pembelajaran merupakan suatu proses peningkatan pengembangan kemampuan diri untuk mengembangkan potensi yang maksimal dalam hidupnya. Peserta didik akan menyukai pembelajaran apabila mendapat kesenangan dari kegiatan yang di ikuti. Selama proses pembelajaran berjalan menyenangkan, maka intensitas dan motivasi yang menyertainya akan sama tinggi dengan minat.

Mayoritas responden mengatakan ketika proses pembelajaran tutor mampu menguasai kelas dilihat dari ketegasan tutor dan membuat suasana belajar yang menyenangkan sehingga tidak ada ketegangan ketika belajar. Peserta didik akan lebih tertarik ketika pembelajaran menggunakan metode diskusi dan praktik karena dapat memberikan pendapat dan mempraktikkan secara langsung pelajaran yang telah didapat.

b. Respon peserta didik terhadap proses pembelajaran

Kegiatan pembelajaran adalah inti kegiatan dalam pendidikan. Segala sesuatu yang telah diprogram akan dilaksanakan dalam proses pembelajaran. Saat kegiatan pembelajaran berlangsung tutor dan warga belajar terlibat dalam sebuah interaksi dengan bahan pelajaran sebagai mediumnya. Ketika berinteraksi warga belajarlah yang lebih aktif bukan tutor. Tutor hanya berperan sebagai motivator dan fasilitator.

Peserta didik di PKBM Mekar Tanjung ketika proses pembelajaran berlangsung memiliki respon untuk mengetahui yang belum diketahui. Ini dapat dilihat ketika proses pembelajaran berlangsung, banyak peserta didik yang mengajukan pertanyaan kepada tutor, seputar materi yang diberikan.

Rasa keingintahuan peserta didik saat kegiatan pembelajaran berlangsung dapat dilihat dari respon saat tutor memberikan tugas. Sebagian responden merasa senang dengan tugas yang diberikan oleh tutor karena itu adalah tugas dan kewajiban mereka.

c. Tingkat pemahaman peserta didik

Pemahaman peserta didik dapat dilihat dari interaksi peserta didik dengan tutor dalam proses pembelajaran. Penggunaan metode-metode yang tepat juga dapat digunakan untuk mengukur sebenarnya sejauh mana pemahaman peserta didik terhadap materi yang telah diberikan. Terlihat pada saat peneliti melakukan pengamatan di dalam kelas ketika proses pembelajaran sedang berlangsung, peserta didik yang banyak bertanya dan menjawab setiap pertanyaan yang diajukan oleh tutor karena paham akan materi yang telah diberikan, sedangkan peserta didik yang hanya diam saja, sebenarnya tidak paham dengan materi yang 
telah diberikan oleh tutor:

Kesimpulannya tingkat pemahaman peserta didik tergantung dari metode pembelajaran yang digunakan oleh tutor dalam penyampaian materi. Jika metode yang digunakan oleh tutor sesuai dengan materi yang ingin disampaikan dan dapat menarik perhatian dari peserta didik serta tidak membosankan, maka materi yang disampaikan tutor dapat diterima dengan baik oleh peserta didik.

\section{Kegiatan Pembelajaran}

a. Perencanaan

1) Persiapan sebelum pembelajaran

Peserta didik akan siap mempelajari sesuatu apabila merasakan perlunya melakukan hal tersebut, fungsi tutor di sini adalah menciptakan kondisi, menyiapkan alat serta prosedur untuk membantu peserta didik menemukan apa yang harus diketahui. Program belajar harus disusun sesuai dengan kebutuhan peserta didik, untuk mengetahui apa saja yang harus dipersiapkan tutor menghadapi kegiatan belajar keesokan harinya, tutor haruslah membuat silabus dan RPP agar kegiatan belajar selanjutnya dapat terencana dengan baik.

Persiapan lainnya, selain membuat silabus dan RPP, yang dilakukan oleh tutor ketika akan memulai kegiatan pembelajaran adalah membaca buku yang akan disampaikan, persiapan metode dan media yang akan digunakan, dan persiapan tugas yang akan diberikan. Namun, tidak semua tutor melakukan persiapan ketika akan memulai pembelajaran.

Dalam pembuatan Silabus dan RPP, tutor mengadopsi dari silabus dan RPP formal akan tetapi disesuaikan dengan kurikulum yang disesuaikan dengan kurikulum program kesetaraan Paket. Untuk media pembelajaran, tutor lebih banyak menggunakan media pembelajaran yang sudah ada, yaitu modul Paket $C$ dan tidak mempunyai inisiatif untuk membuat media lain yang bisa lebih mudah diterima oleh peserta didik.

2) Pengetahuan tutor tentang materi yang akan diajarkan

Sebelum memulai sesuatu, seseorang harus terlebih dahulu tahu apa tujuan dari tindakan yang dilakukan. Begitu juga dengan proses pembelajaran harus ada tujuannya yang dibagi menjadi tujuan umum dan tujuan khusus. Tutor di PKBM Mekar Tanjung tidak pernah menjelaskan tujuan dari materi yang akan diajarkan. Tutor pun tidak pernah diminta untuk membaca dahulu tujuan pembelajaran. Padahal, penjelasan tujuan pembelajaran cukup berpengaruh terhadap motivasi peserta didik untuk ikut belajar.

Materi juga sangat penting untuk dikuasai oleh tutor. Tutor tidak akan dapat melaksanakan tugasnya bila tidak menguasai atau memahami materi yang akan disampaikan, untuk dapat memahami dan meningkatkan pengetahuan tentang materi, tutor dituntut untuk kreatif oleh penanggung jawab PKBM Mekar Tanjung dalam mencari materi penunjang dari sumber mana saja karena keterbatasan buku sumber bacaan.

Tutor di PKBM Mekar Tanjung terlihat menguasai materi yang tengah diberikan. Ini terlihat dari cara tutor menyampaikan materi dan menjawab pertanyaanpertanyaan yang diberikan oleh peserta didik. Namun, tutor memang kurang kreatif dalam mengelola kegiatan pembelajaran. Penyampaian materi yang hanya didapat dari modul Paket $\mathrm{C}$ tanpa memberi contoh dalam kehidupan nyata.

3) Pengulangan materi sebelumnya

Penjelasan isi pelajaran sebelumnya dilakukan bila pelajaran yang akan dipelajari masih berhubungan dengan pelajaran sebelumnya. Jadi, fungsinya untuk mengingatkan pelajaran yang lalu. Pengulangan materi pelajaran yang lalu tidak selalu dilakukan ketika akan memulai pelajaran, tetapi saat berlangsung proses belajar mengajar juga bisa dilakukan.

Proses pembelajaran harus ada tujuannya yang dibagi menjadi tujuan umum dan khusus. Para tutor jarang sekali menjelaskan tujuan khusus dari setiap materi pelajaran, biasanya hanya membacakan dan jika peserta didik ada yang bertanya barulah pendidik menjelaskan. Penjelasan tujuan pembelajaran tidak berpengaruh terhadap motivasi belajar peserta didik, yang terpenting bagaimana cara tutor memotivasi peserta didik untuk belajar.

b. Pelaksanaan Pembelajaran

1) Metode yang digunakan

Metode adalah suatu cara yang digunakan untuk mencapai tujuan yang telah ditetapkan, dalam kegiatan belajar mengajar, metode diperlukan oleh tutor dan penggunaannya bervariasi sesuai dengan tujuan yang ingin dicapai setelah pengajaran berakhir.

Metode pembelajaran yang digunakan oleh pendidik haruslah sesuai dengan media dan materi yang akan dipelajari, pembelajaran hendaknya menekankan kegiatan yang berpusat pada peserta didik. Fokus pembelajaran adalah untuk mengoptimalkan penguasaan hasil pembelajaran secara tuntas. Kegiatan pembelajaran hendaknya dapat meningkatkan perolehan pengetahuan dan keterampilan yang perlu dikuasai oleh peserta didik dalam menyelesaikan masalah. Agar proses penyampaian informasi ke peserta didik berjalan lancar, ada berbagai macam metode yang digunakan oleh tutor dalam pelaksanaan proses pembelajaran yaitu tanya jawab, diskusi, studi lapangan, dan lain-lain. Biasanya tutor selalu mengombinasi lebih dari satu 
metode ketika proses pembelajaran berlangsung.

Metode pembelajaran pada PKBM Mekar

Tanjung harus bersifat andragogi yang menuntut interaktif dari para peserta didik. Metode pembelajarannya juga harus disesuaikan dengan karak-teristik peserta didik, peserta didik di PKBM Mekar Tanjung juga berhak menentukan metode apa yang akan dipakai.

Setiap tutor menggunakan metode yang berbeda pada saat menyampaikan materi, tergantung pada materi pelajaran yang akan diberikan. Untuk materi pelajaran seperti sosiologi, geografi, ekonomi, biasanya tutor lebih banyak menggunakan metode ceramah yang diselingi dengan tanya jawab. Materi pelajaran keterampilan seperti komputer dan metode yang digunakan adalah praktik serta masih ada metode lain yang digunakan oleh tiap tutor, seperti diskusi dan curah pendapat.

Jadi, disimpulkan bahwa tutor di PKBM Mekar Tanjung menggunakan metode yang bervariasi sesuai dengan materi yang diajarkan. Namun, masih ada beberapa tutor yang hanya menggunakan metode ceramah sehingga proses pembelajaran hanya bersifat satu arah dan biasanya jika metode pembelajaran yang digunakan adalah metode ceramah, peserta didik terlihat tidak merespon dengan baik apa yang diterangkan oleh tutor, karena hanya mendengarkan tanpa memberi respon.

2) Media yang digunakan

Media dapat dikatakan juga sebagai alat bantu untuk menyampaikan informasi atau materi pelajaran. Media pelajaran yang digunakan oleh PKBM Mekar Tanjung yaitu buku-buku pelajaran, buku-buku bacaan lainnya, komputer, dan sebagainya sesuai dengan kebutuhan pembelajaran. Penggunaan media dalam proses pembelajaran yang terpenting sesuai dengan materi dan metode apa yang digunakan oleh tutor dan juga disesuaikan dengan kebutuhan dan karakter peserta didik.

Media yang digunakan oleh tutor PKBM Mekar Tanjung adalah buku-buku pelajaran dan bahan bacaan lainnya. Setiap pembelajaran disesuaikan dengan yang ada pada modul Paket C. Hanya tutor Geografi yang menggunakan media lain, yaitu media gambar untuk menerangkan tentang materi yang akan diajarkan pada hari itu.

Dapat disimpulkan bahwa tutor tidak menyiapkan media apa yang akan digunakan untuk pembelajaran hari ini dan hanya beracuan pada modul Paket $C$. Tutor tidak berinisiatif membuat atau membawa media yang dapat merangsang peserta didik untuk tertarik dengan meteri pelajaran yang akan diberikan atau mempermudah peserta didik menerima materi yang diajarkan.
3) Waktu pelaksanaan

Waktu belajar di PKBM Mekar Tanjung ditentukan sesuai dengan kebutuhan peserta didik yang mayoritas bekerja. Rata-rata waktu yang digunakan untuk proses pembelajaran adalah dua sampai empat jam sehari dan biasanya proses pembelajaran dilaksanakan pada sore atau malam hari. Saat proses pembelajaran berlangsung dibuat agar peserta senyaman mungkin dengan didampingi tutor.

Para tutor di PKBM Mekar Tanjung sangat disiplin masalah waktu terbukti dari selalu datang tepat waktu sebelum pembelajaran dimulai. Berbanding terbalik dengan peserta didiknya yang selalu datang terlambat dan datangnya satu persatu, sehingga tutor sangat kesulitan untuk mengatur waktu memulai pembelajaran. Ketika sudah datang ke PKBM pun, peserta didik terkadang jarang langsung masuk ke dalam kelas, lebih banyak menggunakan waktu di luar kelas, dari sekedar merokok ataupun mengobrol dengan temannya.

Saat kegiatan pembelajaran sudah berjalan dan ada materi maupun latihan soal yang belum selesai ataupun peserta didik yang belum mengerti akan materi yang telah disampaikan oleh tutor, terkadang tutor menambah waktu beberapa menit untuk menyelesaikan materi yang belum dimengerti oleh peserta didik. Namun, tambahan waktu ini tidak bisa terlalu lama, karena setelah selesai pembelajaran yang pertama, akan dilanjutkan oleh pembelajaran yang kedua. Selain itu, peserta didik juga mudah bosan, sehingga jika waktu pembelajaran dilihat sudah selesai, sudah lekaslekas membereskan buku-buku.

\section{c. Evaluasi}

Evaluasi dalam proses pembelajaran sangat penting untuk mengetahui kemampuan peserta didik dan melihat sejauh mana tujuan proses pembelajaran tercapai. Di PKBM Mekar Tanjung sama seperti sekolah formal menyediakan rapor dan tes-tes untuk evaluasi. Pelaksanaan evaluasi sudah terjadwal mengikuti sekolah formal.

Untuk mengetahui kemampuan yang telah dicapai warga belajar, berbagai cara telah ditempuh tutor Paket C di PKBM Mekar Tanjung dengan mengevaluasi pembelajaran, dari proses pembelajaran dengan pemberian contoh soal yang dikerjakan tutor hingga langsung pada evaluasi soal berikutnya dengan memberikan tes tertulis atau menguji sejauh mana materi yang telah diserap peserta didik secara langsung dengan pemberian tugas di setiap pokok pembahasan.

Evaluasi merupakan suatu kegiatan yang dilakukan untuk mendapatkan data tentang sejauh mana keberhasilan warga belajar dalam belajar dan keberhasilan tutor dalam mengajar dengan komponen pem- 
belajaran yang terdiri atas penilaian yang dilakukan untuk melihat hasil yang telah dicapai peserta didik dalam penyerapan materi pembelajaran itu berlangsung.

Pemberian latihan soal dilakukan oleh tutor dengan penetapan waktu yang telah ditentukan oleh tutor dalam penyelesaiannya. Walaupun pada pelaksanaannya peserta didik tidak selalu tepat waktu dalam mengerjakannya karena ada beberapa peserta didik yang ketika mengerjakan soal keluar kelas. Pelaksanaan tes dilakukan untuk mengetahui seberapa jauh peserta didik memahami materi-materi yang telah diberikan.

\section{Analisis Data}

Hasil temuan penelitian mengenai kinerja tutor dalam proses pembelajaran Paket C di PKBM Mekar Tanjung dapat dilihat dari urutan proses pembelajaran yang dilakukan oleh tutor. Peneliti melihat bahwa tutor cukup bisa menguasai kelas, peserta didik mudah diajak untuk bekerja sama melaksanakan proses pembelajaran, walaupun ada beberapa peserta didik yang terlihat malas sekali masuk ke dalam kelas dan lebih banyak bermain di luar walaupun proses pembelajaran sudah berlangsung. Biasanya peserta didik yang masih sering terlihat bermain di luar karena memang dalam diri tidak ada minat untuk belajar. $\mathrm{Di}$ setiap pembelajaran, melakukan hal yang sama.

Urutan proses pembelajaran harus ditempuh setiap melaksanakan proses pembelajaran. Apabila satu tahap ditinggalkan, maka tidak dapat dikatakan sebagai proses pembelajaran yang baik.

\section{Tahap Pendahuluan}

Tahap pendahuluan bisa disebut juga tahap persiapan. Sebaiknya dalam menyiapkan proses pembelajaran, tutor harus mempersiapkan dahulu materi yang akan diberikan esok harinya, seperti membuat RPP, media, serta menyiapkan soal. Tutor di PKBM Mekar Tanjung jarang sekali mempersiapkan hal-hal tersebut. Tutor biasanya hanya melihat dari silabus maupun RPP pendidikan formal tanpa mencoba untuk mengubahnya sesuai dengan metode pembelajaran di Paket C.
Materi dan soal latihan, tutor dapatkan hanya dari Modul Paket $\mathrm{C}$, sehingga tidak berinisiatif untuk mencari dari sumber-sumber lain. Akan tetapi, kesiapan untuk mengajar tetap dilakukan, misalnya mempelajari terlebih dahulu materi yang akan diberikan ketika mengajar.

\section{Tahap Penyajian Materi}

Tahap penyajian materi dikatakan sebagai tahap inti, yaitu tahapan memberikan bahan pelajaran yang telah dipelajari oleh tutor sebelumnya. Pada tahap ini, tutor dilihat sudah cukup baik dalam melakukan penyajian materi. Tutor cukup baik menyampaikan materi dan peserta didik diajak untuk aktif dalam proses pembelajaran. Tutor mencoba mengajar sampai peserta didik benar-benar mengerti penjelasan yang diberikan, walaupun ada beberapa peserta didik yang tidak menyimak dan tidak mengerti dengan penjelasan yang diberikan oleh tutor itu tidak mempengaruhi kemampuan tutor.

\section{Tahap Evaluasi dan Tindak Lanjut}

Tujuan tahapan ini adalah untuk mengetahui tingkat keberhasilan dari tahapan penyajian materi. Pemberian evaluasi tidak hanya dilakukan secara terencana setelah selesai tiap materi. Setiap selesai menyampaikan materi, tutor selalu memberikan latihan soal, baik dalam bentuk tulisan maupun lisan. Dalam pemberian soal seperti dimaksud, tutor tidak pernah menentukan waktu kepada peserta didik untuk mengerjakan soal-soal tersebut, yang terpenting adalah peserta didik mampu memahami dan mengerjakan soal dengan benar.

Lain lagi, ketika peserta didik mengerjakan soalsoal yang ada di dalam modul Paket $C$, tutor mencoba memberikan batas waktu untuk mengerjakan soal-soal tersebut dan diberi nilai. Hal ini dimaksudkan melatih peserta didik untuk nantinya mengikuti ujian nasional. Setiap latihan maupun mengerjakan soal, hasilnya akan selalu dibahas bersama-sama, di sini juga bisa terjadi proses pembelajaran agar peserta didik lebih mudah mengikat.

\section{KESIMPULAN}

\section{Kesimpulan}

Berdasarkan hasil analisis data yang dikemukakan pada bab IV, maka dapat ditarik kesimpulan bahwa responden menyatakan seluruh tutor telah melakukan proses pembelajaran sesuai dengan ketentuan yang dijadikan tolok ukur kinerja tutor. Kesimpulan di atas ditunjang dengan data sebagai berikut pertama, mayoritas responden menyatakan bahwa tutor melakukan persiapan sebelum proses pembelajaran dilakukan. Tutor dirasakan masih belum kompeten karena dalam menyampaikan materi dengan jelas dan mudah dimengerti walaupun dengan media dan metode yang sederhana serta penguasaan tutor akan materi yang akan diberikan. 
Kedua, waktu pelaksanaan proses pembelajaran disesuaikan dengan kebutuhan peserta didik, pertemuan dilaksanakan 4 kali pertemuan dalam seminggu, dan 1 hari 2 jam untuk dua mata pelajaran. Tutor juga bertanggung jawab untuk selalu hadir tepat waktu. Hal ini membuat peserta didik juga terpacu untuk hadir pada setiap pembelajaran. Tutor juga mengorbankan waktunya lebih banyak untuk membantu jika ada peserta didik yang belum memahami materi yang telah diberikan.

Ketiga, hasil pembelajaran dapat dilihat dari evaluasi yang dilakukan oleh tutor, adapun bentuk evaluasi yang dilakukan oleh tutor adalah evaluasi harian, yaitu evaluasi yang dilakukan setiap tutor selesai menyampaikan materi ajar. Evaluasi harian dilakukan agar tutor dapat mengetahui tingkat pemahaman dari peserta didik. Evaluasi yang dilakukan tutor tidak mesti dalam bentuk latihan soal, bisa juga dalam bentuk tanya jawab ataupun mengerjakan soal di papan tulis. Evaluasi berkala yaitu evaluasi yang dilakukan pada akhir semester. Evaluasi berkala ini biasanya dilakukan bersamaan dengan evaluasi peserta didik yang bersekolah di sekolah formal. Evaluasi berkala ini dimaksudkan untuk mengetahui kemampuan peserta didik selama proses pembelajaran berlangsung beberapa waktu.

Implikasi

Berdasarkan kesimpulan di atas, maka implikasi pelaksanaan proses pembelajaran ini yang perlu diperhatikan oleh pihak penyelenggara adalah peningkatan media pembelajaran untuk dapat meningkatkan hasil pembelajaran.

Pendidikan luar sekolah perlu memperhatikan masyarakat karena banyak masyarakat yang ingin mempunyai ijazah untuk jenjang pendidikan yang lebih tinggi tetapi selalu terbentur oleh dana dan waktu. Padahal, pendidikan harus dinikmati oleh semua orang. Peran Pendidikan Luar Sekolah sangat penting demi majunya pendidikan dan masyarakat mempunyai keahlian.

\section{Saran}

Saran yang perlu dikemukakan peneliti setelah mengetahui hasil penelitian, sebagai berikut (1) KBM Mekar Tanjung hendaknya pada saat pelaksanaan pembelajaran memberikan motivasi agar responden terus dapat mengembangkan diri dan belajar bersungguh-sungguh dan pada saat proses pembelajaran berlangsung tutor diharapkan dapat lebih maksimal dan mampu dalam penyampaian materi agar materi yang disampaikan dapat diterima oleh peserta didik dengan baik; 2. Pendidikan Luar Sekolah hendaknya mampu berpartisipasi dalam bidang pendidikan bangsa dengan mengembangkan potensi tutor sehingga pelaksanaan pendidikan nonformal dapat tercapai sesuai dengan visi dan misinya; dan 3. tutor hendaknya lebih membuka diri untuk maju dan mau berusaha meningkatkan wawasan, pengetahuan dan pemahaman materi di dalam peningkatan kinerja tutor.

\section{DAFTAR PUSTAKA}

Arikunto, S. (2006). Prosedur Penelitian: Suatu Pendekatan Praktik. Jakarta: Rineka Cipta.

Chourman, I. (1996). Upaya meningkatkan kinerja penelitian di FPIPS IKIP Jakarta. Jakarta, 16 Juli 1996

Departemen Pendidikan Nasional. (2006). Undangundang RI nomor 20 tahun 2003 tentang sistem pendidikan nasional bab 1 pasal 1 ayat 20. Jakarta: Depdiknas

Hakim, T. (2000). Belajar secara efektif. Jakarta: Puspa Swara

Kast, F. E. \& James, E. R. (1992). Organisasi dan manajemen. Jakarta: Bina Aksara

Miles, M.B. \& Huberman, A.M. (1992). Analisis data kualitatif: Buku sumber tentang metode-metode baru. Jakarta: UI Press

Moleong, L.J. (2008). Metodologi penelitian kualitatif.
Bandung: Remaja Rosdakarya.

Rivai, V. \& Sagala, E.J. (2009). Manajemen sumber daya manusia untuk perusahaan: Dari teori ke praktik. Jakarta: Rajawali Press

Sadiman, S. A. dkk. (1996). Media pendidikan. Jakarta: Rajawali Pers

Sugiyono. (2006). Metode penelitian pendidikan. Jakarta: Alfabeta Yin, R.K. (1996). Studi kasus desain dan metode. Jakarta: PT Raja Grafindo Persada

Suparlan, P. (1996). Metodologi penelitian kualitatif. Jakarta: UI

Undang-undang RI No.2 Tahun 2003, Pasal 26 ayat 3 alenia ke 4

Undang-undang RI No.2 Tahun 2005. UU RI.20 tahun 2003 tentang sisdiknas. Jakarta : CV. Eka Jaya 